\title{
Effects of feeding varying levels of bakery waste meal on the performance and carcass values of growing Coturnix quails (Coturnix coturnix japonica)
}

${ }^{1}$ Edache, J. A., ${ }^{2}$ Tuleun, C. D., ${ }^{3}$ Muduudtai, R. U. and ${ }^{1}$ Yisa, A. G.

${ }^{I}$ Federal College of Animal Health and Production Technmology, Vom,

${ }^{2}$ University of Agriculture, Makurdi. ${ }^{3}$ College of Education, Gindiri

Corresponding author: amedzion@yahoo.com; +2348037024295

Abstract

Since bakeries are scattered all over Nigeria and beyond, such feed materials like bakery waste abound and this can be tapped as a feed resource for poultry having little pressure of competition. A feeding trial of 6 weeks duration was conducted to determine the effect of replacing maize with bakery waste of $C P ; 3.32 \%$ and $M E ; 3221.88 \mathrm{kcal} / \mathrm{kg}$ on the performance of growing Japanese quails. Two hundred two-week old quails of mixed sexes were randomly allocated to five diets in a completely randomized design. The five isonitrogenous $(25 \% \mathrm{CP})$ diets incorporated 0, 8.31, 16.61, 24.92 and 28.69\% of bakery waste at the expense of maize. The diets, however, varied in energy levels from 2,706.92 (Diet A) to 2,610.76 kcal/kg ME (Diet E). Diets B (2,679.17), C (2,650.57) and D (2,623.75) were lower than diet $A$. Each diet was replicated three times. Feed intake (21.99, 20.34, 21.25, 23.83 and $22.97 \mathrm{~g} / \mathrm{bird} /$ day), weight gain $(3.39,3.29,3.46,3.61,3.75 \mathrm{~g} / \mathrm{bird} /$ day) and feed conversion ratio $(6.32,6.17$, 6.16, 6.62 and 6.31) did not differ significantly from the control. Water intake was significantly higher $(p<0.05)$ on diet $D(33.78 \mathrm{ml} / \mathrm{b} /$ day) than on diets $A(30.90)$ and $B(30.99)$ only. Water intake on diets $C$ (31.89) and $E(32.91 \mathrm{ml} / \mathrm{bird} /$ day) were not different. Feed cost $/ \mathrm{kg}$ gain was significantly higher $(p<0.05)$ for birds on dietsB (632.00) and A (617.67) than on diets $C$ (542.33) and D (550.67) only. Other differences were not significant. Live weight, slaughter weight, plucked weight and drumstick were better on the diet with 100\% bakery waste. Feed cost per kg diet decreased from 84.62 (diet A) to 78.75 (diet E) and has a cost saving of $6.94 \%$ over the control diet. Therefore, bakery waste could completely replace maize in diets for Japanese quail chicks without adverse effect on performance.

Keywords: Bakery waste meal, water intake, japanese quails.

\section{Introduction}

The major problem of the poultry industries is the escalating price of feed materials resulting in exorbitant products prices (Fafiolu et al., 2004).

Bakery waste consists mainly of dough, sugar, icing, butter and probably other edible products used in the bakery. Since bakeries are scattered all over Nigeria and beyond, such feed materials like bakery waste abound and this can be tapped as a feed resource for poultry having little pressure of competition. Catala-Gregori et al. (2009), Al-Ruquaie et al. (2011) and Ayanrinde et al. (2014) supported the inclusion of bakery waste and bread waste in broiler diets because of the benefits on performance and feed cost. The objective of this study is to determine the effect of replacing maize with bakery waste meal on the performance of growing Japanese quails. Japanese quails are little-known birds that are small-sized and early maturing (Robbins, 1981). Thisearly maturing nature enables them to start laying as early as from the 5th week of life although adult plumage is not attained until the 12th week (Martins, 1987). Persons prone to high blood pressure and related diseases could consume the meat and eggs with less risk of experiencing such conditions. Recommended levels of some nutrients $(\mathrm{CP}, 25 ; \mathrm{ME}, 2,600 \mathrm{kcal} / \mathrm{kg})$ when 
maintained in the feed is useful in achieving optimal performance in growing Japanese quails, (Haruna et al., 1997; Edache et al., 2005). There is paucity of information regarding the use of bakery waste in quail diet hence the need to determine the value of bakery waste for growing Japanese quails.

\section{Materials and methods \\ Birds and management}

200 two-week old Japanese quail birds of mixed sexes obtained from the National Veterinary Research Institute poultry farm were used in this study. They were uniform in size and body conformation and housed in deep litter house partitioned into 15 units with wire mesh to allow for adequate ventilation. There were 13 birds per unit although five units had an extra bird each. Each diet was randomly allocated three units of cages in a completely randomized design. All birds from each unit were weighed at the beginning and weighed weekly for six weeks. The experimental diets were designated A, B, C, D and E. Diet A contained no bakery waste meal. Feed and water were given ad libitum for six weeks.

\section{Bakery waste}

Bakery wastewas collected from several bakeries in Bukuru, Jos South LGA of Plateau State. They were dried and crushed into meals and incorporated into the diets free from mould and weevils. They were analyzed for proximate chemical contents, (AOAC, 2000).

\section{Experimental diets}

Five isonitrogenous $(25 \% \mathrm{CP})$ diets containing graded levels ( 0 , (control), 8.31, $16.61,24.92$ and $28.69 \%$ ) of bakery waste meal at the expense of maize were used in this study. The diets were designated A, B, C, $\mathrm{D}$ and $\mathrm{E}$ respectively and contained metabolizable energy (ME) levels; 2706.92, $2679.17,2650.57,2623.75$ and 2610.76 $\mathrm{kcal} / \mathrm{kg}$ respectively (Table 1 ).

Table 1: Composition of experimental diets (\%)

\begin{tabular}{|c|c|c|c|c|c|}
\hline Ingredients & A & B & $\mathrm{C}$ & D & $\mathbf{E}$ \\
\hline Maize & 33.22 & 23.61 & 13.97 & 4.37 & - \\
\hline Bakery waste meal & - & 8.31 & 16.61 & 24.92 & 28.69 \\
\hline Groundnut cake & 39.08 & 40.38 & 41.72 & 43.01 & 43.61 \\
\hline Palm kernel cake & 20.00 & 20.00 & 20.00 & 20.00 & 20.00 \\
\hline Rice offal & 2.00 & 2.00 & 2.00 & 2.00 & 2.00 \\
\hline Fish meal & 1.50 & 1.50 & 1.50 & 1.50 & 1.50 \\
\hline Bone meal & 2.00 & 2.00 & 2.00 & 2.00 & 2.00 \\
\hline Limestone & 1.50 & 1.50 & 1.50 & 1.50 & 1.50 \\
\hline Premix & 0.25 & 0.25 & 0.25 & 0.25 & 0.25 \\
\hline Salt & 0.25 & 0.25 & 0.25 & 0.25 & 0.25 \\
\hline Methionine & 0.10 & 0.10 & 0.10 & 0.10 & 0.10 \\
\hline Lysine & 0.10 & 0.10 & 0.10 & 0.10 & 0.10 \\
\hline \multicolumn{6}{|c|}{ Calculated composition } \\
\hline $\mathrm{CP}(\%)$ & 25.00 & 25.00 & 25.00 & 25.00 & 25.00 \\
\hline $\mathrm{ME}(\mathrm{Kcal} / \mathrm{kg})$ & 2706.92 & 2679.17 & 2650.57 & 2623.75 & 2610.76 \\
\hline $\mathrm{Ca}(\%)$ & 1.63 & 1.50 & 1.51 & 1.53 & 1.54 \\
\hline $\mathrm{P}(\%)$ & 0.65 & 0.52 & 0.53 & 0.56 & 0.57 \\
\hline C.F. $(\%)$ & 5.25 & 5.13 & 5.01 & 4.88 & 4.82 \\
\hline Cost $/ \operatorname{kg}(\mathrm{N})$ & 84.62 & 82.91 & 81.23 & 79.52 & 78.75 \\
\hline
\end{tabular}




\section{Edache, Tuleun, Muduudtai and Yisa}

\section{Data Collection}

The mean weekly body weights, water intake and feed intake were recorded throughout the experimental period. From the mean body weight and feed intake, feed conversion ratio was calculated. Feed cost $/ \mathrm{kg}$ gain and feed cost $/ \mathrm{kg}$ diet was calculated from prevailing local market price of feed materials. Data collection was subjected to analysis of variance; ANOVA (Steel and Torrie, 1980) and where significant differences occurred, means were separated by Duncan's multiple range test (Duncan's, 1955).

\section{Carcass evaluation}

At the end of the 6 weeks feeding trial, two birds per replicate comprising one male and one females of live weight as close as possible to the mean of the treatment were randomly selected. The birds were starved overnight; weighed and slaughtered, plucked and dressed. Dressing percentage, prime cuts (drumstick, breast, back, wings and thigh) and visceral organs (heart, gizzard, liver, and intestines) expressed as a percentage of live weight was determined according to the procedure outlined by Oluyemi and Roberts (2002) for chicken.

\section{Results and discussion}

Results of measurements recorded in the trial are presented in table 2. Proximate analysis of bakery waste showed that it contained; moisture, $5.15 \%$; crude protein, $3.32 \%$; crude fibre, $0.00 \%$; ether extract, $2.09 \%$; total ash, $1.25 \%$; N.F.E, $87.79 \%$ anddry matter, $94.45 \%$. Values reported for bakery waste samples in this study compare closely to values for bakery waste reported by Al-Tulaihan et al. (2004) and Al-Ruquaie et al. (2011). Values for crude protein and crude fibre were not close. Crude protein was higher (12.22 $12.93 \%)$ in their samples than what was reported in this study probably because of the type of materials used in bakeries in the Middle East. Samples studied in this locality showed zero content for crude fibre as against $0.18-0.53 \%$ in previous studies (Al-Tulaihan et al., 2004; Al-Ruquaie et al., 2011) possibly due to the same factor observed earlier. Moreover, the energy level of the sample used in this study is lower than that $(3,854-3,895 \mathrm{kcal} / \mathrm{kg} \mathrm{ME})$ reported by previous authors (Al-Tulaihan et al., 2004; Al-Ruquaie et al., 2011). Data on feed intake, weight gain and feed conversion ratio are presented in Table 2 . Feed intake and weight gain on the bakery waste diets were similar ( $p$ ?0.05)to the control diet. This report and that of Ayanrinde et al. (2014) were similarin terms of weight gain of broiler starters. However, Ayanrinde et al. (2014) observed significant effect of bread waste on feed intake of starter broilers. This was not observed in this study and may be due to the differences in the type of birds used. The non significant effect of the diets on feed intake, weight gain and feed conversion ratio in this study has been reported earlier (Al-Ruquaie et al., 2011). Water intake was significantly higher $(\mathrm{p}<0.05)$ on $\operatorname{diet} \mathrm{D}(33.78 \mathrm{ml} / \mathrm{b} /$ day $)$ than on diets A (30.90) and B (30.99) only. Water intake on diets $\mathrm{C}$ (31.89) and $\mathrm{E}$ $(32.91 \mathrm{ml} / \mathrm{bird} /$ day $)$ were not different.Feed cost / kg gain was significantly higher $(\mathrm{p}<0.05)$ on dietsB $(25 \%)$ and $\mathrm{A}(0 \%)$ than on diets $\mathrm{C}(50 \%)$ and $\mathrm{D}(75 \%)$. The value on diet $\mathrm{E}(100 \%)$ did not differ significantly from the control and other diets containing bakery waste showing an inconsistent trend.Similar result has been reported by Adeyemo et al. (2013) for broilers fed biscuit waste. Feed cost $/ \mathrm{kg}$ feed decreased consistently as the levels of bakery waste increased in the diet and have a cost saving of $6.94 \%$ over the control diet. 
The performance and carcass values of growing Coturnix quails (Coturnix coturnix japonica)

Table 2: Effects of various bakery waste meal levels on parameters measured

\begin{tabular}{lllllll}
\hline Parameters & A & B & C & D & E & SEM \\
\hline Feed intake $(\mathrm{g} / \mathrm{b} / \mathrm{d})$ & 21.44 & 20.32 & 21.31 & 23.93 & 23.39 & $1.68 \mathrm{~N} . \mathrm{S}$ \\
Water intake $(\mathrm{ml} / \mathrm{b} / \mathrm{d})$ & $30.90 \mathrm{a}$ & $30.99 \mathrm{a}$ & $31.89 \mathrm{ab}$ & $33.78 \mathrm{~b}$ & $32.91 \mathrm{ab}$ & $0.98^{*}$ \\
Weight gain $(\mathrm{g} / \mathrm{b} / \mathrm{d})$ & 3.39 & 3.29 & 3.46 & 3.61 & 3.75 & $0.20 \mathrm{~N} . \mathrm{S}$ \\
Feed/gain ratio & 6.32 & 6.17 & 6.16 & 6.62 & 6.31 & $0.40 \mathrm{~N} . \mathrm{S}$ \\
Feed cost/kg gain & $617.67 \mathrm{~b}$ & $632.00 \mathrm{~b}$ & $542.33 \mathrm{a}$ & $550.67 \mathrm{a}$ & $587.00 \mathrm{ab}$ & $35.47^{*}$ \\
Initial weight $(\mathrm{g} / \mathrm{bird})$ & $22.62 \mathrm{a}$ & $17.86 \mathrm{~b}$ & $19.05 \mathrm{ab}$ & $19.05 \mathrm{ab}$ & $19.05 \mathrm{ab}$ & $1.84^{*}$ \\
Final weight $(\mathrm{g} / \mathrm{bird})$ & $146.67 \mathrm{~b}$ & $158.33 \mathrm{~b}$ & $150.00 \mathrm{~b}$ & $150.00 \mathrm{~b}$ & $175.00 \mathrm{a}$ & $6.95 \mathrm{NS}$ \\
\hline
\end{tabular}

a,b. Means with different superscripts within a row differ significantly $(\mathbf{P}<0.05)$

Live weight (Table 3) was significantly higher $(\mathrm{p}<0.05)$ on $\operatorname{diet} \mathrm{E}$ than on the control and other diets. Slaughter and plucked weight were significantly higher on diet $\mathrm{E}$ than on the control. Thus showing a trend of increased live weight on the diet with complete replacement with bakery waste.This result is contrary to the report of Adeyemo et al. (2013) for broilers. It is possible that for Japanese quail, a better balance between energy and protein with increased content of biscuit waste might have promoted higher body weights and hence higher values of these carcass measures. Dressed weight was similar across the diets. It is possible that the major differences in the previous measures were responsible to internal organs. Therefore, with the removal of internal organs, dressed weight balanced out across the diets. This is contrary to the report of Al- Tulaihan et al. (2004) for broilers and may be due to differences in species used. Gizzard percentage decreased significantly from diet $\mathrm{A}$ and was lowest on diet D but appreciated slightly on diet $\mathrm{E}$. This is similar to what was reported by Adeyemo et al. (2013) for broilers.Aderoluet al. (2007) had shown that gizzard weight must increase due to increased activity of the gizzard to blend feed. The tendency to high gizzard value on the complete replacement with bakery waste is not clear since bakery waste was finer than maize. The value for drumstick followed the same trend with gizzard showing a higher value for birds on diet $\mathrm{E}$ indicating increased

Table 3: Effects of different levels of bakery waste meal on carcass values of Japanese quails

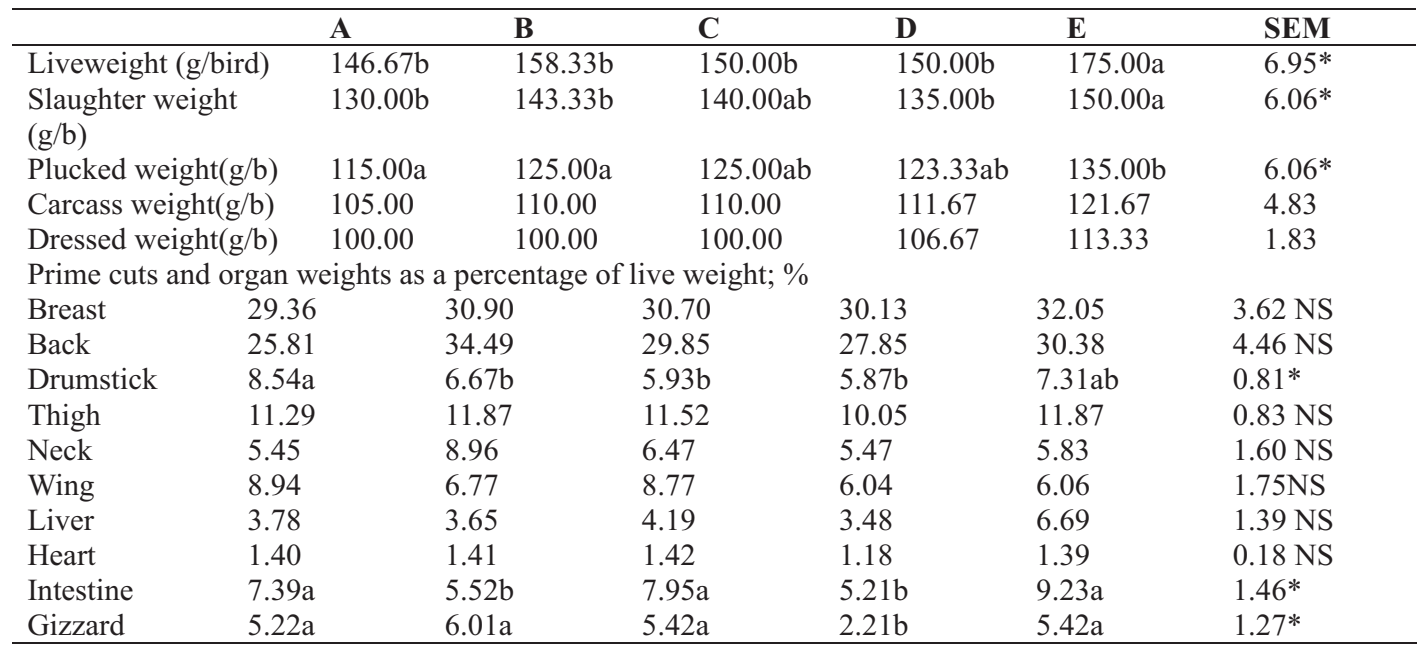

a, b, means in the same row with different superscripts differ significantly $\quad$ (P¥0.05). SEM = standard error of mean, N.S = not significant, A; control (no bakery waste meal) B; Diet with $25.60 \%$ bakery waste meal, C; Diet with $50 \%$ bakery waste meal, D; Diet with $75 \%$ bakery waste meal, E; Diet with $100 \%$ bakery waste meal. 


\section{Edache, Tuleun, Muduudtai and Yisa}

musculature. This may be because bakery waste has higher sugar content leading to increased water and feed intake. Increased sugar intake results in acidity of the body which promotes thirst.Intestine percentage was significantly higher on $\operatorname{diet} \mathrm{A}, \mathrm{C}$ and $\mathrm{E}$ than on diets $\mathrm{B}$ and $\mathrm{D}$ showing no particular trend. Values measured in this study compared favourably with reports by Yisaet al.(2013) on weight for weight basis.

\section{Conclusion}

Bakery waste is obtainable from several bakeries around us and at times constitutes a waste disposal burden. The escalating cost of poultry feed could effectively be alleviated by use of cheaper feed resources like this. Comparison of the mean values of parameters (feed intake, weight gain and feed/gain ratio) showed that the mean values of these parameters were similar (p?0.05). However, water intake was significantly higher on diet $\mathrm{D}$ than on diets $\mathrm{A}$ and $\mathrm{B}$ only. Feed cost/kg gain decreased significantly but inconsistently with increasing content of bakery waste. Bakery waste seemed to promote greater live weight, drumstick and gizzard percentage than maize and it's recommended to completely replace maize in the diet of quail chicks for profitable performance.

\section{Acknowledgement}

The authors are grateful to the Provost, FCAH\&PT., Vom for the support.

\section{References}

Adeyemo, G. O., Oni, O. R. and Longe, O. G. 2013. Effect of dietary biscuit waste on performance and carcass characteristics of broilers. Food Science and Quality Management.ISSN 2224-6088 (paper) ISSN 2225-0557 (Online) Vol. 12, 2013. www.iiste.org
Aderolu, A. Z., Iyayi, F. A. and Onilude, A. A. 2007. Performance, organ relative weight, serum and haematology parameters in broiler finisher fed biodegraded brewer's dried grain. Pakistan Journal of Nutrition 6(3): 204-208, 2007 ISSN, 16805194

Al-Ruquaie, I. M., Swillam, S. A., AlBatshan and Shafey, T. M. 2011. Performance, nutrient utilization and carcass characteristics and economic impact of broiler chickens fed extruded bakery waste. Journal of Animal and Veterinary Advances. Vol. 10, issue 16, 2061-2066.

Al-TulaihanAbdullatif, A., HuthailNajib and Salah M. Al-Eid 2004. The nutritional evaluation of locally produced dried bakery waste (DBW) in broiler diets. Pakistani Journal of Nutrition 3(5): 294-299

AOAC 2000 Official methods of analysis.Association of Official Analytical Chemist Inc. 15THEd.Washington.

Ayanrinde, O. J., Owosibo, A. O. and Adeyemo, A. A. 2014. Performance characteristics of broilers fed bread waste based diets. International Journal of Modern Plant and Animal $\mathrm{S}$ c i e n c e s. 2 ( 1 ): 1 11www.modernscientificpress.com/ journals/IJ Plant aspx

Catala-Gregori, P., Garcia, V., Madrid, J., Orengo, J. and Hernandez, F. 2009. Inclusion of dried bakery products in high fat broiler diets: Effect on pellet quality, performance, nutrient digestibility and organ weights. Asian-Aust. $J$. Anim. Sci. Vol. 22,(5): 686-693. www.ajas.info

Duncans, D. B. 1955. Multiple range and multiple F - test. Biometrics, 11: 1 - 
42

Edache, J. A., Musa, U., Haruna, E. S., Karsin, P. D., Esilonu, J. O. and Jibrin, I. I. 2005. Calcium requirement of Japanese quail (Coturnixcoturnix japonica) chicks in Plateau State, Nigeria; Nig. J. Anim. Prod. 32:246-252

Fafiolu, A. O., Oduguwa, O. O., Ikeobi, C. O. N., Onwuka, C. F. I. and Adebule, M. A. 2004 . Performance and egg quality assessment of laying hens fed malted sorghum sprouts based diets. Proceedings of the 9th Annual Conference of Animal Science Association of Nigeria; 2004, Abakaliki, Nigeria; Ebonyi State University, 2004, p.33-35
Haruna, E. S., Musa, U., Okewole, P. A., Shamaki, D., Lombin, L. H., Molokwu, J. U., Edache, J. A., and Karsin, P. D. 1997. Protein requirement of quail chicks in Plateau State, Nigeria. Nigerian Veterinary Journal. 18: 108-113

Martins, B. 1987. Guinness World birds, Guinness superlatives Ltd, pp. 158

Robbins, G. E. S. 1981. Quail, their breeding and management. Publisher-World Pheasant Association(WPA) 1, 9, 10.

Steel, R. G. D and Torrie, J. A. 1980. Principle and procedure of Statistics.A biometrical approach.2nd ed. McGraw Hill Book Co. New York, USA.

Received: $10^{\text {th }}$ March, 2017

Accepted: 27 July, 2017 